\title{
INDOOR THERMAL CONDITION OF FACTORY BUILDING IN BANGLADESH
}

\author{
Muhammed Abdullah Al Sayem Khan ${ }^{1)}$, Mohd. Hamdan Ahmad ${ }^{2)}$ and Tareef Hayat Khan ${ }^{3)}$ \\ ${ }^{1)}$ M. Arch Candidate, Universiti Teknologi Malaysia, \\ ${ }^{2,3)}$ Department of Architecture, Universiti Teknologi Malaysia
}

\begin{abstract}
Bangladesh is a developing country and has a lot of factories for different products for local use and also export to abroad. Garments industries are one of the top most items of exported items. A huge number of populations are working in garments industries. But these factories are not well designed in sense of the thermal environment. Workers experiences sickness related to indoor environment. The productions of these factories are affected due to employees' health condition. The research is done in two different methods. One is empirical data collection using thermal data loggers and the other is questionnaire survey on the spots for three factory buildings. The field study was conducted in four different months of the same year during winter and summer period. Expected findings of this research are that the indoor environment is not comfortable for works at day time during summer season. This research will help the factory workers in providing a comfortable thermal environment and also help the employers or factory owners to increase their production margin.
\end{abstract}

Keywords: Indoor thermal, factory building.

\section{INTRODUCTION}

The use of energy for cooling, air movement and air-conditioning of the indoor environment is by now one of the largest sectors in energy consumption in Bangladesh. Last two decades have seen a significant increase in HVAC energy use in developing and newly industrialized countries (MAllick, 1996; Abro 1994) some of which are located close to the equator thus having warm and humid tropical climatic conditions. Bangladesh is lying between $20^{\circ} 34^{\prime} \mathrm{N}$ to $26^{\circ} 33^{\prime} \mathrm{N}$ and $88^{\circ} 01^{\prime} \mathrm{E}$ to $92^{\circ} 41^{\prime} \mathrm{E}$, and in the IndoMalayan Realm where many light-work manufacturing factories are located. In this context, it would be useful to maintain an adequate level of thermal comfort in free running factory buildings if it is possible to sustain the same productivity level. Previous studies (Kosonen, 2004), have shown that the level of thermal comfort could have some effects on the productivity levels. Usage of higher ventilation rates as opposed to air conditioning could consume significantly less energy in warm humid tropical climatic conditions of Bangladesh. This research will find out the preferred temperature range for Bangladesh factory workers who are acclimatized to warm humid climatic conditions had to be explored. The real preferred temperature range by workers can be differed by few degrees of Celsius due to various reasons such as expectations, clothing and adoptability (Andamon, 2006).

The industry of Bangladesh is contributing to export earnings, foreign currency, employment creation for men and women. But Like many other developing countries, occupational health of worker is a neglected part in Bangladesh. Very little industrial management is concerned to the work place environment and health of the workers. As a result, the industrial management does not provide any attention to the work place injuries, sickness and environment. The workers bear the responsibility to their health and safety. But the industry owners and management must take necessary actions to heath condition of employees.

\section{AIM AND OBJECTIVE OF THE RESEARCH}

The objective of this research is to evaluate the thermal behavior of factory buildings in Bangladesh. The field study is conducted to find out the influence of winter and summer periods in factory buildings and to study the effect of thermal condition at workplace of employees.

\section{CLIMATIC CONDITION OF BANGLADESH}

The climate of Bangladesh, based on a wide range use of classification by Atkinson (Koenigsberger, 1973), and it is characterized as a warmhumid subtropical climate. Generally, in Bangladesh has a short and dry winter and the summer is long and wet with heavy rainfall. Although a large part of land mass of Bangladesh is laid above the Tropic of Cancer. The nature of the local climate being a tropical is attributed to the local geographical charac- 
ters. The Himalayan mountain range and Tibet Plateau are situated in the north and it causes a significant amount of rainfall in the whole year (Hossain \& Nooruddin, 1993; Rashid, 1991). The humidity is remaining high throughout the whole year in summer season and especially from the month of June to September and it is often over $80 \%$. Meteorologically the climate of Bangladesh is divided into four distinct seasons-winter, pre-monsoon, monsoon and post-monsoon (Hossain \& Nooruddin, 1993) as showed in Table 1.

Table 1. Classification of the seasons and weather condition of Bangladesh

\begin{tabular}{|c|c|c|c|}
\hline $\begin{array}{c}\text { Bangla } \\
\text { Calendar } \\
\text { Month }\end{array}$ & $\begin{array}{c}\text { Traditional } \\
\text { Seasons }\end{array}$ & $\begin{array}{c}\text { Meteorological } \\
\text { Seasons }\end{array}$ & $\begin{array}{c}\text { Gregorian } \\
\text { Calendar } \\
\text { Months }\end{array}$ \\
\hline Chaitra & Bashanta & Pre-monsoon (hot-dry) & March \\
\hline Baishakh & Grisha & Pre-monsoon (hot-dry) & April \\
\hline Jaishtha & Grisha & Pre-monsoon (hot-dry) & May \\
\hline Ashaar & Barsha & Monsoon (hot-wet) & June \\
\hline Srabon & Barsha & Monsoon (hot-wet) & July \\
\hline Bhadra & Sharat & Monsoon (hot-wet) & August \\
\hline Ashin & Sharat & Monsoon (hot-wet) & September \\
\hline Kartik & Hemanta & Post monsoon (hot-wet) & October \\
\hline Arahayon & Hemanta & Post monsoon (hot-wet) & November \\
\hline Poush & Sheet & Winter ( cool-dry) & December \\
\hline Magh & Sheet & Winter ( cool-dry) & January \\
\hline Falgun & Bashanta & Winter ( cool-dry) & February \\
\hline
\end{tabular}

The winter is cool and dry, the pre-monsoon is hot and dry, monsoon and the post-monsoon periods are hot and wet with rainfall. December to February are the months of winter season, which are characterized by very minimal rainfall, cold winds flow from north-side of the country, the mean air temperature $21^{\circ} \mathrm{C}$ and maximum remain below $26^{\circ} \mathrm{C}$. In the northern part of Bangladesh, the minimum temperature in winter season often drops below $4^{\circ} \mathrm{C}$. The month of March, April and May is covered by the pre-monsoon period and it is characterized by occasional thunderstorm, and a maximum temperature of $34^{\circ} \mathrm{C}$. The monsoon is the longest season and it is covering the month of June to September. In this monsoon period torrential rainfall occurs and is recorded from $781 \mathrm{~mm}$ to $1499 \mathrm{~mm}$ in the Dhaka, with the average humidity above $80 \%$ and an average temperature of $31^{\circ} \mathrm{C}$. The post-monsoon season remains between October and November month. It is also a transitional period of winter season with infrequent rainfalls and air temperature stay below $30^{\circ} \mathrm{C}$.

\section{METHODOLOGY}

The research will find out the indoor temperature for the factory buildings. This work consists of identifying for evaluating the thermal condition of workplace and the preferred temperature range for worker in which the work rate of employees are giving their best efforts.

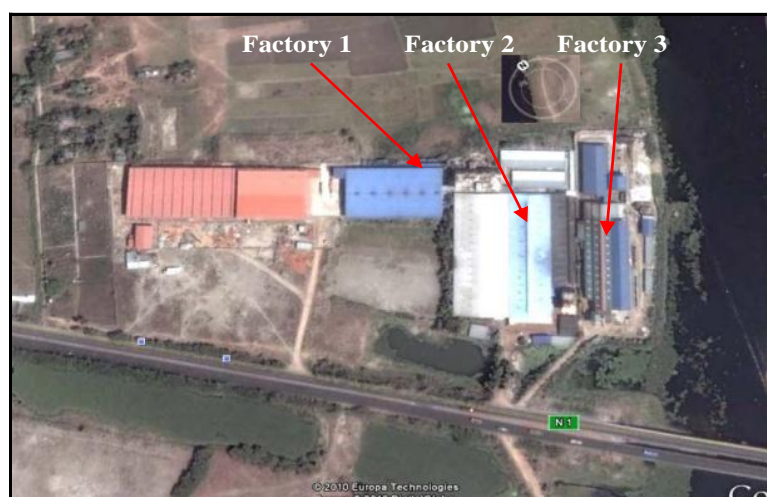

Figure 1. Location of three adjacent factory buildings

Three factory buildings were selected to find out the indoor thermal conditions. The three factory buildings used in this study were chosen to obtain a rectangular shape in Bangladesh at Gajaria Area. The buildings were selected on the basis of orientation, climatic zone, building's surroundings and more over same production and machineries.

Data was collected for every ten minutes interval for fifteen days in first phase. Data was collected in second phase in selected months. Five days data was taken per minute to verify air temperature change at site and found that within eight to ten minutes air temperature has no major or minor change. The mean air temperature increases from January to April, then remains almost constant up to September, and start to decreases up to January. (Karmokar \& Khatum, 1993). For this reason field investigation is carried out for selected periods. The questionnaire serve is also done with workers of the three factory buildings with 80 nos. of workers as 250 nos. of worker is working at a time in each factory.

The Hobo thermal data loggers were installed in each factory building at two level heights and in the middle of the factory building. To take the human level temperature data logger sensor (TM C6-HA and TM C50-HA) is fixed beside the worker's standing position in front of the machines. The thermal data logger was kept in 2.4 meter level to record the indoor temperature and relative humidity of factory buildings. Data was collected by a method which is given below in Table 2.

The general practice in Bangladesh particularly among architects and environmental engineers is to use recorded data from the meteorological department station for designing buildings. 
Tabel 2. Tabular format of data collection method

\begin{tabular}{|c|c|c|c|c|c|c|}
\hline \multirow{2}{*}{ Season } & \multirow{2}{*}{ Month } & \multirow{2}{*}{ Date } & \multicolumn{3}{|c|}{ Collected Data (Air Temperature) } & \multirow{2}{*}{$\begin{array}{c}\begin{array}{c}\text { Relative Humidity } \\
\text { indoor }\end{array} \\
\end{array}$} \\
\hline & & & Indoor $1.5 \mathrm{~m}$ level (Ti) & (Indoor) $2.5 \mathrm{~m}$ level $(\mathrm{Tu})$ & Outdoor (To) & \\
\hline \multirow[t]{2}{*}{ Winter } & December & - & $\mathrm{Ti}$ & $\mathrm{Tu}$ & To & Rhi \\
\hline & January & - & $\mathrm{Ti}$ & $\mathrm{Tu}$ & To & Rhi \\
\hline \multirow[t]{4}{*}{ Summer } & March & - & $\mathrm{Ti}$ & $\mathrm{Tu}$ & To & Rhi \\
\hline & April & - & $\mathrm{Ti}$ & $\mathrm{Tu}$ & To & Rhi \\
\hline & May & - & $\mathrm{Ti}$ & $\mathrm{Tu}$ & To & Rhi \\
\hline & June & - & $\mathrm{Ti}$ & $\mathrm{Tu}$ & To & Rhi \\
\hline
\end{tabular}

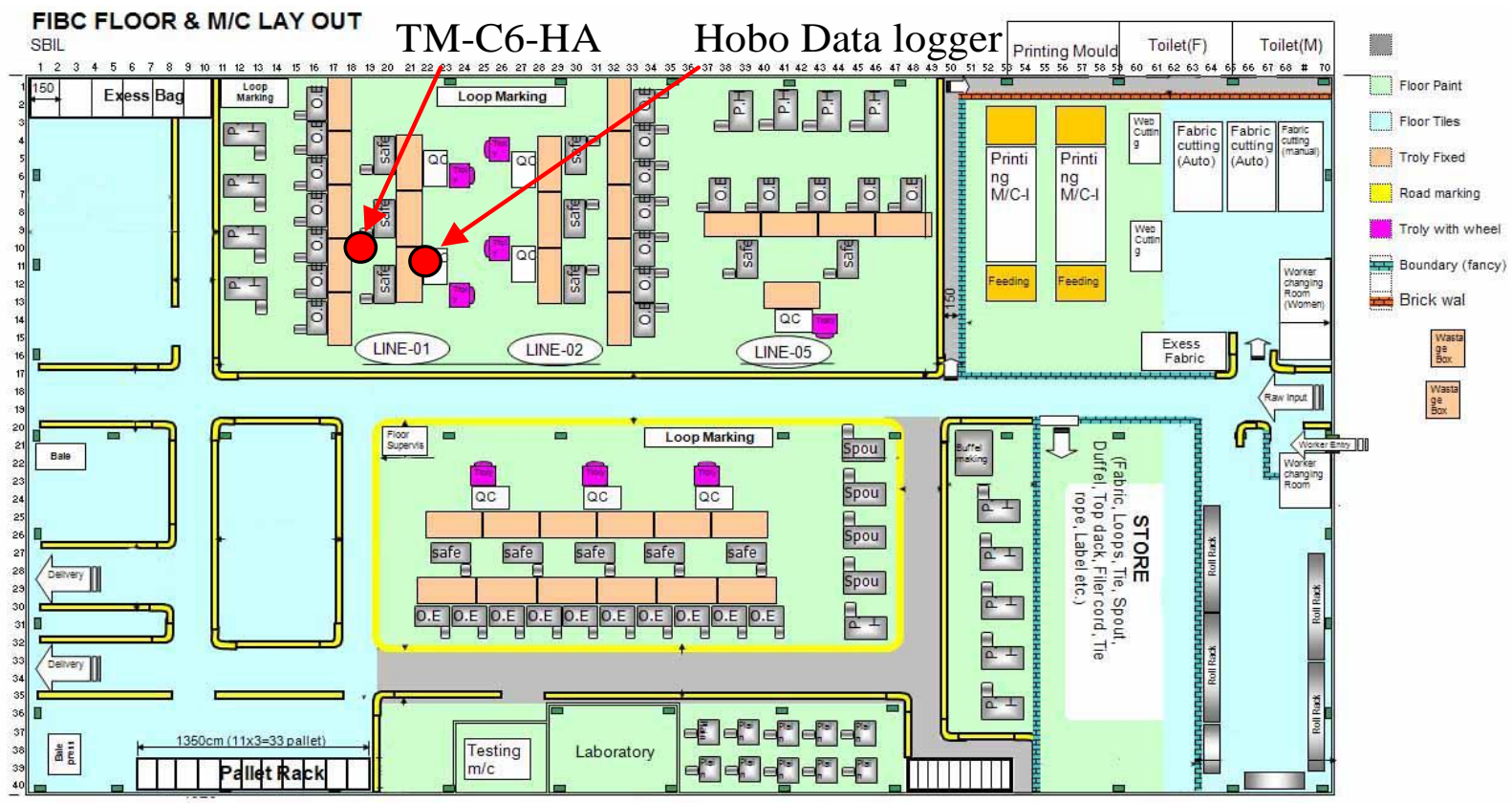

Figure 2. Position of Hobo data logger and sensor in factory building
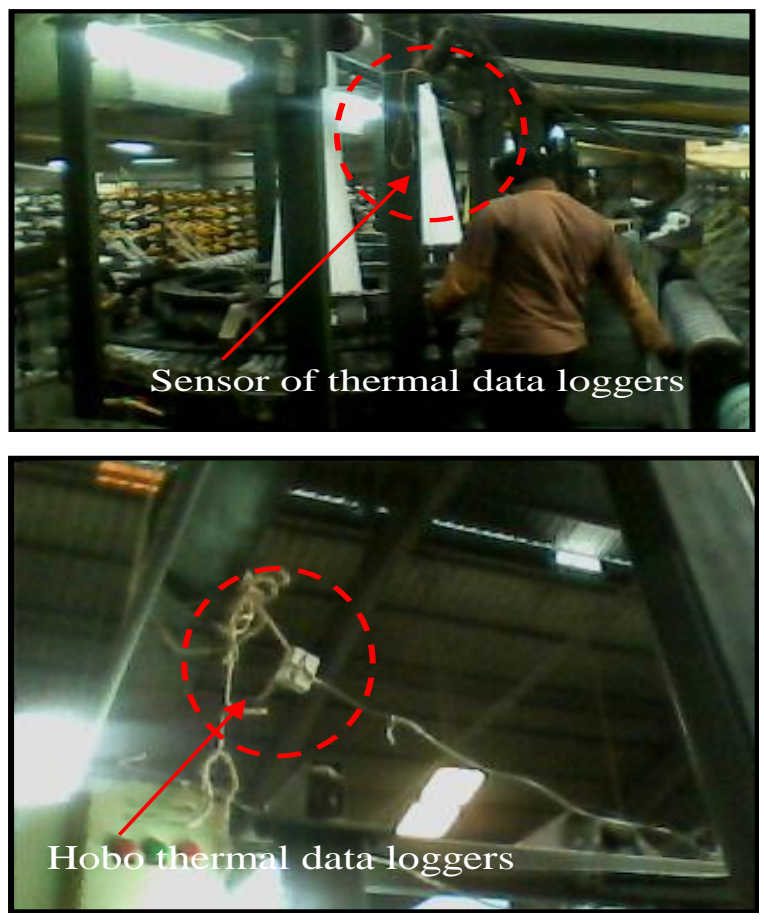

Figure 3. Position of Hobo data logger and sensor in factory building at different level.
It is evident from the field measurements that indiscriminate use of meteorological data in the context of Dhaka city, of a considerable size and diverse texture, is inherently inaccurate (Sabbir Ahmed, 1995; Bijon Behari Sharma, 2002; Abu Mukim Mirdha, 2002). The environmental data was recorded at the meteorological station are affected by the surroundings of that particular observation site. The observation station site is surrounded by high-rise buildings and data is measured at $1.2 \mathrm{~m}$ level from the ground. The outdoor temperature of selected site has been found to be the most notable indicator. For these reasons, this research's field measurements were decided to be done on site by physical measurements. The field study and the subsequent results of this research were based on the following objectives:

- To record primary environment data in indoor of factory buildings in reference to the microclimate of Dhaka city.

- To understand the thermal performance of factory buildings.

- To evaluate the indoor thermal condition in terms of indoor comfort requirements to judge the performance of the factory buildings. 


\section{RESULTS}

Comparison of Indoor and Outdoor air temperature at factory 1 in July

This study examines thermal behavior of selected factory buildings. This factory is constructed with powder coated corrugated iron sheet, peripheral apron of $2 \mathrm{~m}$ in width and by local grass with some
$3 \mathrm{~m}$ height trees. Plants provided shade on wall surface of south side of the factory 1 . The experiment is carried out to find out the thermal behavior of indoor environment during summer season. Indoor ambient air temperature of spaces examined according to their corresponding outdoor ambient air temperature. The field study result is plotted in graph with all average data from thermal data logger.

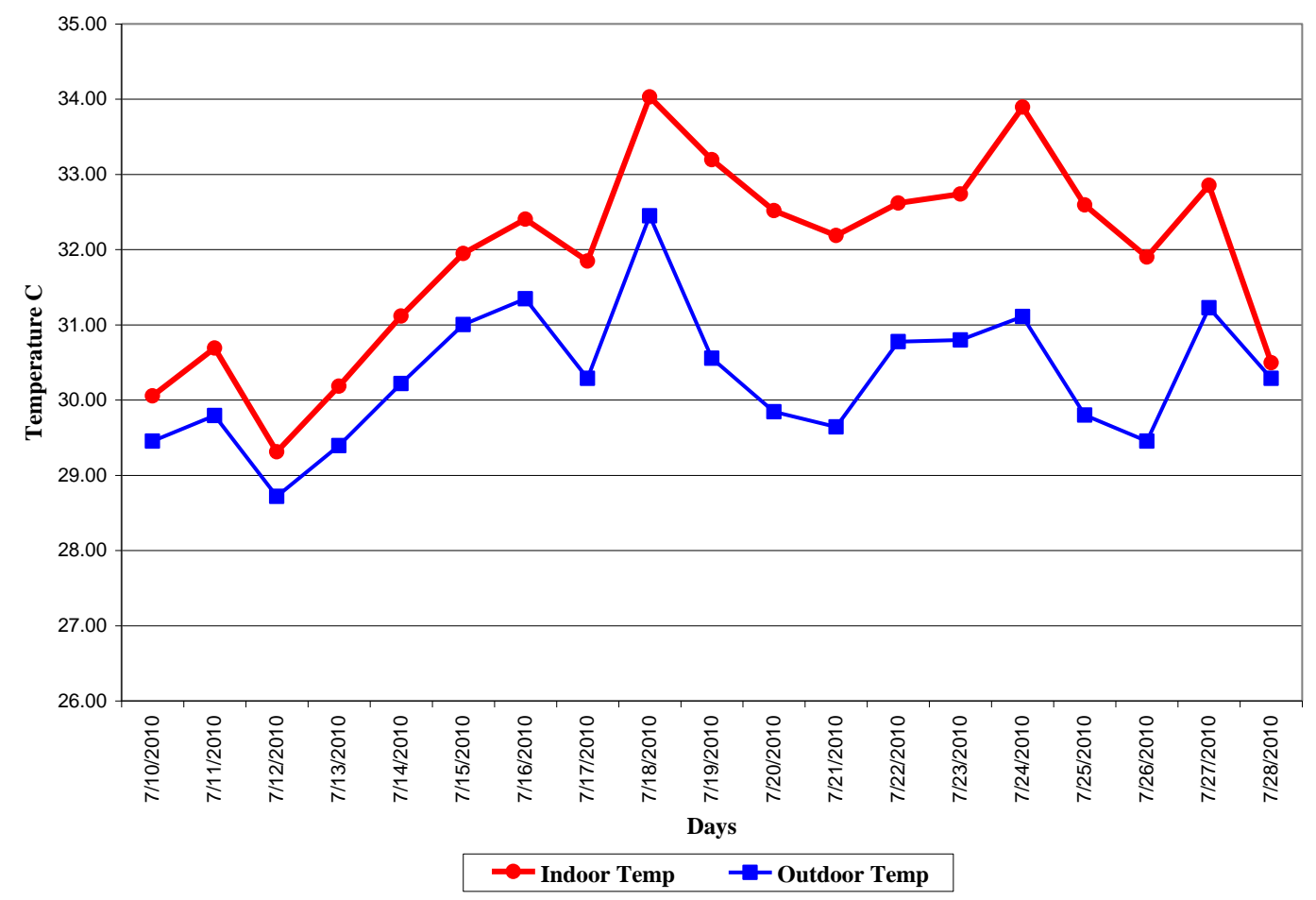

Figure 4. Graph profile of comparison between average indoor air temperature and average outdoor air temperatures of factory 1 in July.

Table 3. Indoor and outdoor maximum air temperature during July of selected day

\begin{tabular}{|c|c|c|c|c|}
\hline \multicolumn{2}{|c|}{ Summer Season } & \multicolumn{2}{|c|}{ Factory 1} & \multirow[b]{2}{*}{ Relationship } \\
\hline Date & Indoor air Temperature ${ }^{\circ} \mathbf{C} \mathbf{T}_{\mathrm{i}}$ & Outdoor air Temperature ${ }^{\circ} \mathrm{C} \mathbf{T}_{0}$ & Difference $\%\left(\mathbf{T}_{\mathbf{i}}-\mathbf{T}_{0}\right) / \mathbf{T}_{\mathbf{i}}$ & \\
\hline $10^{\text {th }}$ July & 30.05 & 29.45 & 2.04 & $\mathbf{T}_{\mathrm{i}}>\mathbf{T}_{\mathbf{0}}$ \\
\hline $11^{\text {th }}$ July & 30.69 & 29.79 & 3.02 & $T_{i}>T_{0}$ \\
\hline $12^{\text {th }}$ July & 29.31 & 28.72 & 2.07 & $\mathbf{T}_{\mathrm{i}}>\mathbf{T}_{0}$ \\
\hline $13^{\text {th }}$ July & 30.18 & 29.39 & 2.70 & $\mathbf{T}_{\mathrm{i}}>\mathbf{T}_{\mathrm{o}}$ \\
\hline $14^{\text {th }}$ July & 31.12 & 30.22 & 2.97 & $\mathbf{T}_{\mathrm{i}}>\mathrm{T}_{\mathbf{0}}$ \\
\hline $15^{\text {th }}$ July & 31.95 & 31.00 & 3.05 & $\mathbf{T}_{\mathrm{i}}>\mathrm{T}_{\mathbf{0}}$ \\
\hline $16^{\text {th }}$ July & 32.40 & 31.34 & 3.38 & $\mathbf{T}_{\mathrm{i}}>\mathbf{T}_{\mathbf{0}}$ \\
\hline $17^{\text {th }}$ July & 31.85 & 30.29 & 6.15 & $\mathbf{T}_{\mathrm{i}}>\mathbf{T}_{\mathbf{o}}$ \\
\hline $18^{\text {th }}$ July & 34.03 & 32.45 & 4.87 & $\mathbf{T}_{\mathrm{i}}>\mathbf{T}_{\mathbf{0}}$ \\
\hline $19^{\text {th }}$ July & 33.19 & 30.56 & 8.64 & $\mathbf{T}_{\mathrm{i}}>\mathbf{T}_{\mathbf{0}}$ \\
\hline $20^{\text {th }}$ July & 32.52 & 29.84 & 8.96 & $T_{i}>T_{0}$ \\
\hline $21^{\text {th }}$ July & 32.19 & 29.64 & 8.58 & $T_{i}>T_{0}$ \\
\hline $22^{\text {th }}$ July & 32.62 & 30.78 & 6.98 & $T_{i}>T_{o}$ \\
\hline $23^{\text {th }}$ July & 32.74 & 30.80 & 6.30 & $\mathbf{T}_{\mathrm{i}}>\mathbf{T}_{0}$ \\
\hline $24^{\text {th }}$ July & 33.89 & 31.11 & 8.95 & $T_{i}>T_{o}$ \\
\hline $25^{\text {th }}$ July & 32.59 & 29.80 & 9.37 & $\mathbf{T}_{\mathrm{i}}>\mathbf{T}_{0}$ \\
\hline $26^{\text {th }}$ July & 31.90 & 29.45 & 8.32 & $\mathbf{T}_{\mathrm{i}}>\mathbf{T}_{\mathrm{o}}$ \\
\hline $27^{\text {th }}$ July & 32.85 & 31.23 & 6.21 & $\mathbf{T}_{\mathrm{i}}>\mathbf{T}_{0}$ \\
\hline $28^{\text {th }}$ July & 30.50 & 30.29 & 0.69 & $T_{i}>T_{0}$ \\
\hline
\end{tabular}


Figure 4 illustrates the comparison of air temperature obtained from indoor and outdoor over some clear day. The observations derive from the comparisons indicate that indoor air temperature is higher than outdoor temperature during day time. The average maximum air temperature of indoor is recorded at $34.03^{\circ} \mathrm{C}$ and for outdoor $32.45^{\circ} \mathrm{C}$. The difference between average indoor air temperatures and outdoor air temperature is $1.58^{\circ} \mathrm{C}$ in same day. Indoor air temperature is maximum $9.37 \%$ higher than outdoor temperature. On the selected days, from the table 3, it is clear that indoor air temperature is always higher than outdoor air temperature during working day time. For the seasonal change, a sometimes rainfall start late of month and also temperature depends on the amount of rainfall. From the figure 4, the average temperature difference of indoor at night stays more than the difference of indoor temperature during late month as the rain fall occurred. The night temperature also depends on the surroundings of the selected sites, for rainfall it contained lower temperature during night time. This indoor environment of factory buildings is not desirable for the workers in their working hours, where they are continuously work for 8 to 10 hours.

\section{Comparison of Indoor and Outdoor Daily Air Temperature at Factory 1 in July}

The thermal behavior study of the environmental research tried to find out both indoor environmental quality of working place and surrounding outdoor ambient environment of the factory buildings. Workplace is also gaining heat from human body and also from machineries in factory buildings. An important question is that how much temperature is obtained at workplace during hot period of the day. This field study compares the indoor air temperatures and

Table 4. Tabular format of indoor and outdoor air temperature difference from $15^{\text {th }}$ to $17^{\text {th }}$ July

\begin{tabular}{|c|c|c|c|c|c|c|c|}
\hline \multicolumn{2}{|l|}{$\overline{\text { Factory } 1}$} & \multicolumn{6}{|c|}{ Summer Season } \\
\hline \multirow{3}{*}{ Date } & \multirow{3}{*}{ Max, Min } & \multicolumn{2}{|c|}{ Indoor air Temperature } & \multicolumn{2}{|c|}{ Outdoor air Temperature } & \multirow{2}{*}{$\begin{array}{c}\text { Difference \% } \\
\left(\mathbf{T}_{\mathrm{i}}-\mathrm{T}_{0}\right) / \mathrm{T}_{\mathrm{i}} \\
\end{array}$} & \multirow[t]{2}{*}{ Relationship } \\
\hline & & ${ }^{\circ} \mathbf{C}$ & $\mathbf{T}_{\mathbf{i}}$ & ${ }^{\circ} \mathbf{C}$ & $\mathbf{T}_{0}$ & & \\
\hline & & $\operatorname{Max}$ & Min & Max & Min & & \\
\hline \multirow[t]{2}{*}{$\overline{15^{\text {th }} \mathrm{July}}$} & $12 \mathrm{pm}$ & 36.71 & & 34.64 & & 6.64 & $\overline{T_{i}>T_{o}}$ \\
\hline & $5 \mathrm{am}$ & & 29.10 & & 28.77 & 1.1 & $\mathbf{T}_{\mathrm{i}}>\mathbf{T}_{0}$ \\
\hline \multirow[t]{2}{*}{$16^{\text {th }}$ July } & $2 \mathrm{pm}$ & 37.10 & & 34.71 & & 6.44 & $\mathbf{T}_{\mathrm{i}}>\mathbf{T}_{\mathbf{o}}$ \\
\hline & $5 \mathrm{am}$ & & 29.10 & & 29.10 & 0 & $\mathbf{T}_{\mathrm{i}}=\mathbf{T}_{0}$ \\
\hline \multirow[t]{2}{*}{$17^{\text {th }}$ July } & $12 \mathrm{pm}$ & 36.13 & & 33.24 & & 7.99 & $\mathbf{T}_{\mathrm{i}}>\mathbf{T}_{\mathbf{0}}$ \\
\hline & $5 \mathrm{am}$ & & 29.10 & & 28.83 & 0.92 & $T_{i}>T_{0}$ \\
\hline
\end{tabular}

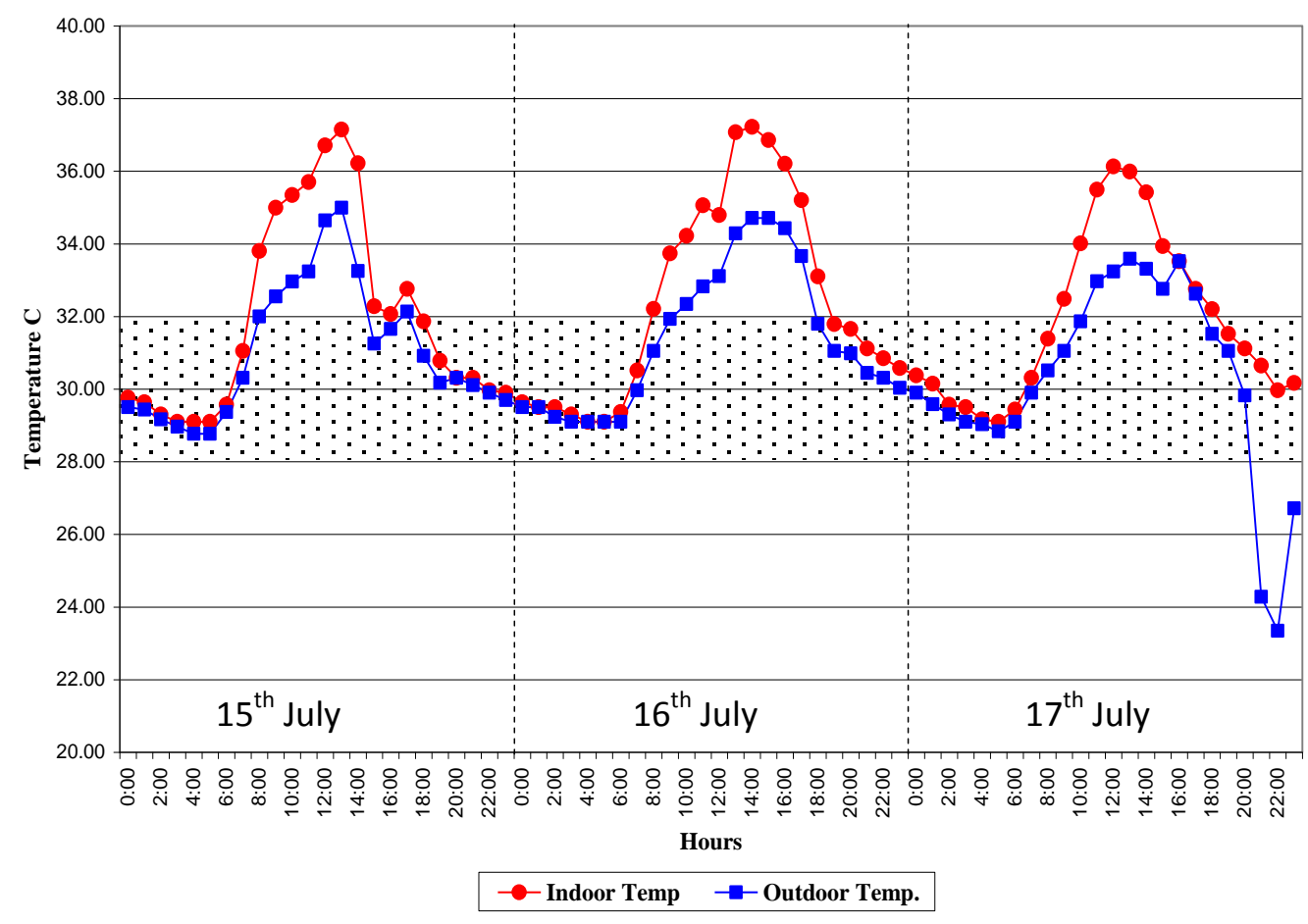

Figure 5. Graph profile of comparison between daily indoor air temperature and daily outdoor air temperatures of factory 1 in July. 
general outdoor ambient air temperature. Measurements are carried out to evaluate the indoor thermal environment of workplace. The study explored the thermal condition of factories in warm-humid tropical climate.

For factory 1 the maximum indoor air temperature by $3.06^{\circ} \mathrm{C}$ as compared to outdoor during the hottest summer period, when outdoor temperature was recorded at $33.24^{\circ} \mathrm{C}$. According to lower limit and upper limit of comfort temperature for factory building is $24^{\circ} \mathrm{C}$ to $32^{\circ} \mathrm{C}$. An internal temperature of $34^{\circ} \mathrm{C}$ with plenty of air movement $\left(0.6 \mathrm{~ms}^{-1}\right)$ could be acceptable for the factory workers who have acclimatized to the warm humid climatic conditions. (Szokolay, 1991). Comfort zone analysis for Bangla- desh according to Sharma, Ali and Mallick (1995) during the summer season, the comfort temperature range is between $28^{\circ} \mathrm{C}$ to $32^{\circ} \mathrm{C}$ while relative humidity range is fixed between $\mathbf{5 0 \%}$ (lower limit) to $90 \%$ (upper limit). From the figure 5, it is also observed that at night the outdoor temperature and indoor air temperature remain almost same. According to the graph profile, the indoor temperatures stayed above comfort temperature range for around 5 hours of the day which is maximum duration of working hours. It is not desirable condition for factory buildings during hot summer day.

To further compare the indoor and outdoor air temperature of same month other three dates was selected. Results which are presented in Table 5 are

Table 5. Tabular format of indoor and outdoor air temperature difference from $24^{\text {th }}$ to $26^{\text {th }}$ July

\begin{tabular}{|c|c|c|c|c|c|c|c|}
\hline \multicolumn{4}{|l|}{ Factory 1} & \multicolumn{4}{|c|}{ Summer Season } \\
\hline \multirow{3}{*}{ Date } & \multirow{3}{*}{ Max,Min } & \multicolumn{2}{|c|}{ Indoor air Temperature } & \multicolumn{2}{|c|}{ Outdoor air Temperature } & \multirow{3}{*}{$\begin{array}{c}\text { Difference } \% \\
\left(\mathbf{T}_{\mathrm{i}}-\mathbf{T}_{\mathrm{o}}\right) / \mathbf{T}_{\mathbf{i}}\end{array}$} & \multirow{3}{*}{ Relationship } \\
\hline & & ${ }^{\circ} \mathbf{C}$ & $\mathbf{T}_{\mathbf{i}}$ & ${ }^{\circ} \mathbf{C}$ & $T_{0}$ & & \\
\hline & & Max & Min & Max & Min & & \\
\hline \multirow[t]{2}{*}{$\overline{24^{\text {th }} \text { July }}$} & $3 \mathrm{pm}$ & 38.70 & & 36.56 & & 8.11 & $T_{i}>T_{o}$ \\
\hline & $5 \mathrm{am}$ & & 30.71 & & 28.31 & 7.8 & $T_{i}>T_{0}$ \\
\hline \multirow[t]{2}{*}{$25^{\text {th }} \mathrm{July}$} & $12 \mathrm{pm}$ & 36.71 & & 32.08 & & 10.16 & $\mathbf{T}_{\mathrm{i}}>\mathbf{T}_{\mathrm{o}}$ \\
\hline & $5 \mathrm{am}$ & & 30.71 & & 28.31 & 7.8 & $\mathbf{T}_{\mathrm{i}}=\mathbf{T}_{0}$ \\
\hline \multirow[t]{2}{*}{$26^{\text {th }}$ July } & $1 \mathrm{pm}$ & 36.42 & & 32.21 & & 9.06 & $\mathbf{T}_{\mathrm{i}}>\mathbf{T}_{0}$ \\
\hline & $5 \mathrm{am}$ & & 29.37 & & 27.12 & 7.66 & $T_{i}>T_{0}$ \\
\hline
\end{tabular}

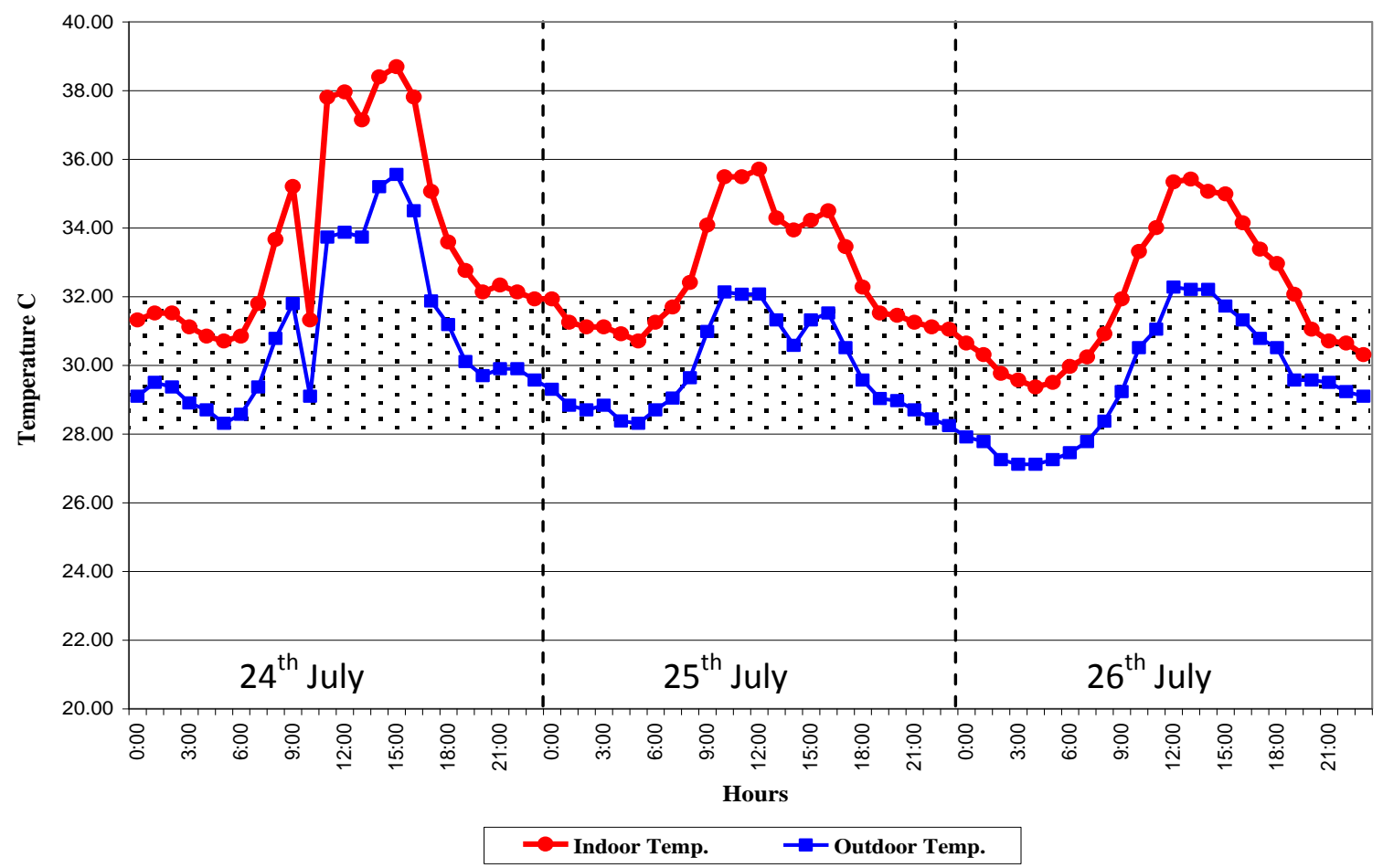

Figure 6. Graph profile of comparison between daily indoor air temperature and daily outdoor air temperatures of factory 1 in July 
to find out the thermal behavior of factory 1 building. From data analysis of Table 5 and Figure 6, it is observed that the indoor environment temperature is also higher compared to outdoor air temperature. From the graph profile it was observed that suddenly temperature was dropped as a rain fall occurred from 9 am to $11 \mathrm{am}$. After rain fall, the temperature of both indoor and outdoor rose very quickly. The solar radiation leads to heat gain during day and heat loss is found during night time. For this reason, air temperature fluctuation of indoor environment is higher than outdoor air temperature. Indoor temperatures become $3.63^{\circ} \mathrm{C}$ higher than outdoor air temperature during day time. Figure 6 shows that at night, indoor air temperature of factory 1 building's graph profile stayed $2^{\circ} \mathrm{C}$ higher than outdoor air temperature but within the comfort temperature range. The maximum daily fluctuation for factory 1 is measured at $8^{\circ} \mathrm{C}$. This occurred due to surroundings of the factory 1 building. The analysis indicates that the indoor temperature is always stayed higher than outdoor temperature both day and night time.

\section{CONCLUSION}

It is obvious that indoor environment of factory building can be modified by the micro-climate through changing many climatic parameters. But the impact of indoor temperatures was well documented in this comparative study. It is simple because temperature is closely related with thermal behavior of factory building and suburban micro-climate. If the factory building can run free running in warm-humid tropical climate could have many advantages such as increase workers work rate, natural ventilation for workers and natural lighting conditions. Now a day, the management of factory 1 is using the industrial exhaust fan to reduce the indoor hot air to outside. The ceiling fans are used at $3 \mathrm{~m}$ level for indoor air movement slowly. Every grid of the factory plan consist two windows of $2 \mathrm{~m}$ but only one side $(1 \mathrm{~m})$ can open for ventilation. All the findings of this field study will be helpful to the owners of factory buildings in Bangladesh in the context of suburban area. Some features can also be counted with outdoor environmental factors such as vegetation or landscaping that limits the increase of air temperature during the daytime in summer period. By the understanding of thermal behavior of existing situation of factory building, owners can improve the indoor environment quality to increase their production.

\section{REFERENCES}

Abu Mukim Mridha. (2002). A study of thermal performance of operable roof insulation, with special reference to Dhaka.

Ahmed, S., Hossain, M.A., and Sultana, N. (1993). A study on the Physical Relationship \& Interaction urban between Urban and Rural climates in Bangladesh, Proc., International Technical Conference on Tropical Urban Climates, Dhaka.

Andamon M.M. (2006). Thermal comfort and building energy consumption in the Philippine context: the 23 conference on passive and low energy architecture, Geneva, Switzerland, 6-8 September.

Bijon Behari Sharma. (2002). A study of the factors for thermal comfort in residential high-rise in Dhaka city.

Mallick, F.H. (1996). 'Thermal comfort and building design in the tropical climates', Energy and Buildings 23, 161-167.

Hossain, M.E., and Nooruddin, M. (1993). Some Aspects of Urban Climates of Dhaka City, International Technical Conference on Tropical Urban Climates, Dhaka, Bangladesh.

Karmokar, S. and Khatun, A. (1993). On the Variability and Probabilistic Extremes of some Climatic Elements over Dhaka, International Technical Conference on Tropical Urban Climates, Dhaka.

Koenigsberger, et al. (1973). Manual of tropical Housing and Building Design, Part I, Orient Longman.

Koenigsberger, O.H., Ingersoll, T.G., Mayhew, A., Szokolay, S.V. (1973). Manual of Tropical Housing and Building, Part one: Climate Design, rep. 1988, Orient Longman Ltd., India.

R. Kosonen, F. Tan. (2004). Assessment of productivity loss in air-conditioned buildings using PMV index. Energy and Buildings 36, 987-993.

R.S. Abro. (1994), 'Recognition of passive cooling techniques', Renewable Energy 5(II), 11431146.

Sharma and Ali. (1986). Tropical Summer Index- A Study of Thermal Comfort of Indian Subjects, Building and Environment 21(1), Pergamon Press.

Szokolay, S.V. (1980). Manual of Tropical Horsing and Building, Part 1 Climatic Design. London: Longman. 